\title{
Enteral fluid therapy in neonatal calves and features of commercially available electrolyte solutions in Brazil
}

\author{
Gabriela de Castro Bregadioli ${ }^{*}$ Priscilla Fajardo Valente Pereira $^{2}$ \\ Karina Keller Marques da Costa Flaiban ${ }^{3}$ José Dantas Ribeiro Filho ${ }^{4}$ Júlio Augusto Naylor Lisbôa $^{2}$
}

\begin{abstract}
'Programa de Pós-graduação em Ciência Animal, Centro de Ciências Agrárias (CCA), Universidade Estadual de Londrina (UEL), Campus Universitário, Rodovia Celso Garcia Cid, PR 445, Km 380, 86057-970, Londrina, PR, Brasil. E-mail: gc.bregadioli@hotmail.com. "Corresponding author.

${ }^{2}$ Departamento de Clínicas Veterinárias (DCV), Centro de Ciências Agrárias (CCA), Universidade Estadual de Londrina (UEL), Londrina, PR, Brasil. ${ }^{3}$ Departamento de Medicina Veterinária Preventiva (DMVP), Centro de Ciências Agrárias (CCA), Universidade Estadual de Londrina (UEL), Londrina, PR, Brasil. ${ }^{4}$ Departamento de Veterinária, Universidade Federal de Viçosa (UFV), Viçosa, MG, Brasil.
\end{abstract}

\begin{abstract}
According to the World Health Organization, the development of orally replacement fluids and electrolytes was one of the most significant advances of the twentieth century, markedly reducing mortality from diarrheal children. In veterinary medicine, oral electrolyte solutions (OES) are routinely used to treat diarrheic neonatal calves in order to correct water, electrolyte and acid base imbalances. In North America, the use of OES is routine and there are at least 20 commercial alternatives. Use of OES has increased in recent years in Brazil, but just five commercial products are currently available. The OES should contain, in suitable concentrations, electrolytes, glucose and an alkalizing agent to ensure its therapeutic efficacy. This review aimed to address the therapeutic importance of OES for neonatal calves and to evaluate the compositions and characteristics of those commercially available in Brazil.
\end{abstract}

Key words: electrolyte imbalance, diarrhea, oral electrolyte solution, dehydration, acid base imbalance.

Hidratação enteral em bezerros neonatos e características das soluções eletrolíticas disponíveis comercialmente no Brasil

RESUMO: De acordo com a Organização Mundial da Saúde, o desenvolvimento da reposição de fluidos e eletrólitos por via oral foi um dos avanços mais significativos da medicina no século XX, reduzindo marcadamente a mortalidade de crianças diarreicas. Na medicina veterinária, as soluções eletrolíticas orais (SEO) são rotineiramente utilizadas no tratamento de bezerros neonatos diarreicos com o intuito de corrigir os desequilibrios hidroeletroliticos e ácido base. Na América do Norte, o emprego de SEO é habitual e existem, pelo menos, 20 alternativas comerciais. O uso das SEO se expandiu nos últimos anos, no Brasil, havendo, atualmente, cinco produtos disponíveis no comércio. As SEO devem veicular eletrólitos, glicose e um agente alcalinizante em concentrações apropriadas para garantir a sua eficácia terapêutica. Essa revisão tem o objetivo de abordar a importância e uso terapêutico das SEO para bezerros neonatos, além de avaliar as composições e características das disponíveis comercialmente no mercado brasileiro.

Palavras-chave: desequilíbrio hidroeletrolítico, diarreia, solução eletrolítica oral, desidratação, desequilíbrio ácido base.

\section{INTRODUCTION}

The fluid therapy is indicated for the treatment of diseases that determine dehydration and electrolyte and acid base imbalances and is; therefore, commonly used in ruminants medicine, especially in calves. The goals of the replacement of fluids and electrolytes are the correction of present imbalances, the restoration of blood volume and adequate tissue perfusion and the treatment of shock in animals (CONSTABLE, 2003).

Fluid and electrolyte replacement can be performed by enteral hydration $(\mathrm{EH})$ or by intravenous infusion (IV). The EH has advantages over IV and should be the modality of choice whenever possible (BERCHTOLD, 2009). It is easier and cheaper, and should be considered equally effective, whenever the gastrointestinal transit is present and dehydration is not marked (CONSTABLE, 2003).

Diarrhea is the main disease that affects neonatal calves and can cause mortality due to the imbalances that are installed (SMITH, 2009). Economic losses are related to the death and to additional costs with drugs, labor and veterinary care. When animals survive, the losses occur due to low performance and reduction in the daily body weight gain (MILLEMANN, 2009).

In the treatment of diarrheic calves the therapy with oral electrolyte solutions (OES) is the most important measure. The goal is to correct the dehydration, to reverse the hyponatremia and the 
relative hyperchloremia, and to correct the metabolic acidosis, which are the commonly present imbalances in these animals (NAYLOR et al., 2006). The appropriate OES should, therefore, contain electrolytes, an alkalizing agent, as acetate or bicarbonate, and glucose as an energy source (SMITH \& BERCHTOLD, 2014). This review aimed to address the importance and therapeutic use of the OES for neonatal calves and to evaluate the compositions and characteristics of those commercially available in Brazil.

\section{Enteral hydration}

According to the World Health Organization (WHO) the development of therapy with OES was the most significant advance of twentieth century medicine, avoiding the death of thousands of children affected by diarrhea in poor countries (SANTOSHAM et al., 1997). Drawing on the successful experience with children, the $\mathrm{EH}$ became the main treatment protocol of diarrhea in calves due to its practicality and ease administration and its low cost (SMITH, 2009; SMITH \& BERCHTOLD, 2014).

Different viral, bacterial and protozoal enteropathogenic agents, in associated infections or not, can cause diarrhea in the neonatal calf(LANGONI et al., 2004). Regardless of which agent(s) is (are) involved, the elimination of watery stools causes dehydration, electrolyte imbalances, and metabolic acidosis, which are marked if the diarrhea is prolonged (SMITH, 2009). In severe cases with profuse diarrhea, the daily loss of fluid in the feces varies from $13 \%$ to $18 \%$ of body weight (BW), and in extreme cases, this value may reach $21 \%$ (BERCHTOLD, 2009).

The most common imbalances that follow dehydration in cases of diarrhea are hyponatremia, potassium $\left(\mathrm{K}^{+}\right)$depletion and metabolic acidosis (NAYLOR et al., 2006). Hyponatremia may be accompanied by hyperchloremia, which can be absolute or relative to the plasma sodium $\left(\mathrm{Na}^{+}\right)$concentration (CONSTABLE et al., 2001; SMITH, 2009; SMITH $\&$ BERCHTOLD, 2014). Hypoglycemia and negative energy balance tend to occur when the intake of milk or its substitutes is decreased due to depression and anorexia or to intended restriction of the offer (CONSTABLE et al., 2001).

To determine the amount of fluid to be replaced for rehydration it is necessary to estimate the water body deficits, which is the degree of dehydration (CONSTABLE, 2003). The dehydration is classified as mild (loss of fluids between 6 and $8 \%$ BW), moderate (between 8 and $10 \% \mathrm{BW}$ ), and severe (between 10 and $12 \% \mathrm{BW}$ ), and the evaluation is based on clinical signs, such as behavior, degree of retraction of the eyeball in the orbit (enophthalmos), and skin turgor (SMITH, 2009).

In cases of mild dehydration, the administration of OES is indicated because it is usually enough to restore homeostasis. Conversely, in severe dehydration, in the hypovolemic shock, and in the marked electrolyte and acid base imbalances, IV replacement of fluid is the correct and inevitable decision because EH is not efficient for the rapid and complete correction of imbalances (NAYLOR et al., 2006; BERCHTOLD, 2009). The moderate degree of dehydration is the situation that requires decision making about the route of administration to be employed. At this level of imbalance, the EH may also be effective.

Compared to the IV administration, $\mathrm{EH}$ has reduced costs and has other advantages avoiding the need for restraint for a long time, the need for constant vigilance, and the possible complications related to the needle or catheter maintenance within the vein (RIBEIRO FILHO et al., 2011). It is; therefore, a practical and effective therapeutic measure that should be the first choice whenever possible. However, the following conditions must necessarily be present in the neonatal calf: sucking reflex and transit in the digestive system. Although, these two conditions are considered essential for oral rehydration to be instituted (NAYLOR, 1990), in the authors' experience, even calves slightly depressed and without vigorous sucking reflex can be efficiently rehydrated with enteral administration of OES or by esophageal tube. The absence or the slowness of abomasal and/or intestinal motility is undoubtedly the decisive factor affecting the efficiency of $\mathrm{EH}$.

In addition to the existing deficits that will be corrected by the replacement volume, the maintenance rate must also be considered. This volume must be sufficient to replace the daily loss of fluids that occurs with feces, urine, expired air and through the skin, which ranges between 120 and $150 \mathrm{~mL} \mathrm{~kg}^{-1}$ day $^{-1}$ in neonatal calves (RADOSTITS et al., 2007). The replacement and maintenance volumes must be calculated and summed, determining thereby, the total volume that the dehydrated calf should receive in that day. The amount of milk or milk substitute that will be ingested by the calf must be subtracted of this total calculated volume. In cases of profuse diarrhea with frequent eliminations, the excessive loss of fluids and electrolytes in feces should not be neglected. The total volume of fluid calculated for the calf on that day (replacement volume plus maintenance volume) should be increased in order to supply this additional loss.

The volume of $2 \mathrm{~L}$ of $\mathrm{OES}$ can be administered at once to calves with $\geq 40 \mathrm{~kg}$ BW, 
because it does not exceed the abomasum capacity. In smaller and lighter calves, the volume of OES should be reevaluated avoiding to cause excessive dilation of the abomasum. In such cases, the total volume can be fractioned and given more times a day.

The OES must be administered between the morning and afternoon milk feedings, respecting the minimum interval of two hours before or after the meal. This avoids any interference with milk clotting in the abomasum and its digestion (NAYLOR, 1990). This is particularly important when the OES contains sodium bicarbonate as alkalizing agent. The interference seems to be smaller or absent when the OES contains sodium acetate in its composition (SEN et al., 2006; MARSHALL et al., 2008; SMITH et al., 2012).

Finally, it is noteworthy that the OES should be administered, preferably per os with bottle feeding, because the active suction is usually accompanied by the reticular groove reflex, leading the solution directly into the omasum channel and abomasum (RODRIGUES et al., 2002). The enteral administration, through esophageal tube is reserved for apathetic or anorexic calves that refuse to suck or have slow and not vigorous suction. In the authors' experience, it is not infrequent that beef calves refuse to suck, even if they are not depressed. For these, the enteral administration is a feasible alternative.

\section{Composition of the oral electrolyte solutions (OES)}

The ideal composition of the OES differs according to the age or physiological condition of the animal to be treated, and it is true for cattle as well as other ruminant species. Two categories should be considered: the suckling calf and animals with fore stomach fermentative activity already developed. Dehydrated suckling calves usually present metabolic acidosis and the addition of an alkalizing agent in the OES is required. In cattle with full rumination, conversely, metabolic alkalosis is usually more frequent than acidosis (CONSTABLE et al., 2001; CONSTABLE, 2003; ROUSSEL, 2014). The OES presented in this review are appropriate; therefore, for hydration of the suckling calves and are not suitable for hydration of older animals.

The ideal OES should contain enough sodium to supply the deficit and normalize the extracellular fluid space volume; two or more agents which facilitate water and sodium absorption by the gut (glucose, citrate, acetate, propionate or glycine); an alkalizing agent (acetate or bicarbonate) capable of correcting the metabolic acidosis; and an energy source, since most of diarrheic calves develop negative energy balance (CONSTABLE et al., 2001; CONSTABLE, 2003; SMITH, 2009; SMITH \& BERCHTOLD, 2014).

According to the recommendations of CONSTABLE et al. (2001), CONSTABLE (2003), and SMITH (2009), the following characteristics define the suitable composition of the $\mathrm{OES}: \mathrm{Na}^{+}$concentration between 90 and $130 \mathrm{mEq} \mathrm{L}^{-1} ; \mathrm{K}^{+}$between 10 and $20 \mathrm{mEq}$ $\mathrm{L}^{-1}$; chloride $\left(\mathrm{Cl}^{-}\right)$between 40 and $80 \mathrm{mEq} \mathrm{L}^{-1} ; \mathrm{HCO}_{3}^{-}$or metabolizable bases (acetate) between 40 and $80 \mathrm{mEq}$ $\mathrm{L}^{-1}$; effective strong ion difference (effective SID) between 60 and $80 \mathrm{mEq} \mathrm{L}^{-1}$; sodium and glucose ratio between 1:1 and 3:1; and osmolarity ranging between 300 and $600 \mathrm{mOsm} \mathrm{L}^{-1}$.

Use of sodium bicarbonate $\left(\mathrm{NaHCO}_{3}\right)$ as an alkalizing agent is common in OES and has the advantage of combining directly with $\mathrm{H}^{+}$ions, exerting direct buffering effect. However, solutions with high $\mathrm{HCO}_{3}{ }^{-}$concentration alkalize the abomasum and the proximal portion of the small intestine, interfering with milk clotting and digestion (SMITH et al., 2012). As result of the increase in the intestinal lumen $\mathrm{pH}$, bacterial growth is favored and can worsen the diarrhea (SEN et al., 2006; MARSHALL et al., 2008). Metabolizable bases, such as acetate and citrate, are absorbed and posteriorly metabolized without causing alkalization of the gastrointestinal lumen (SEN et al., 2006). Sodium acetate is the most recommended alkalizing agent in OES because it is rapidly metabolized increasing blood $\mathrm{pH}$; facilitates the absorption of water and sodium in the jejunum; and does not interfere with the digestion of the milk in the abomasum (SEN et al., 2006; SMITH et al., 2012).

Based on the physiological range of bovine plasma osmolarity (between 270 and 306mOsm $\mathrm{L}^{-1}$; (RADOSTITS et al., 2007), it is possible to classify the electrolyte solutions as hypoosmolar $\left(<300 \mathrm{mOsm} \mathrm{L}^{-1}\right)$, isoosmolar (300 to $\left.312 \mathrm{mOsm} \mathrm{L}^{-1}\right)$, and hyperosmolar $\left(>312 \mathrm{mOsm} \mathrm{L}^{-1}\right)$ (CONSTABLE, 2003). The amount of glucose present in the OES can vary widely and is the main determinant factor for its osmolality (LEVY et al., 1990). The hyperosmotic OES marketed in the North America have high concentration of glucose and are used to diarrheic calves when the daily milk intake is intentionally reduced or suspended. This aims to compensate the energy deficit generated by the lower milk intake (SMITH, 2009). The hyperosmolar OES provided; therefore, more energy to calves than the iso- and hypoosmolar solutions.

The osmolarity of the intestinal lumen is 600mOsm L-1 (JODAL \& LUNDGREN, 1986) and the osmolarity of the hypertonic OES should not exceed this value. Solutions with high osmolarity may 
worsen the diarrhea because the resulting increase in the intraluminal tonicity may cause hypersecretion of water and electrolytes; which is even more pronounced in animals with damaged intestinal villi (SMITH \& BERCHTOLD, 2014). In addition, the intake of OES with high osmolarity can slow the abomasal emptying and compromise the aboral transit of the digesta (NOURI \& CONSTABLE, 2006; SEN et al., 2006; SEN et al., 2009).

Diarrheic calves should not be deprived of milk or its substitutes and the OES should work as an "extra meal" for the purpose of hydration and not as an option to replace diet. The suspension of milk intake resulted in a greater weight loss (FETTMANN et al., 1986; GARTHWAITE et al., 1994; GOODELL et al., 2012), and in more severe energy imbalance and hypoglycemia, which is not compensated by OES intake even those containing high levels of glucose. If the calf is depressed or refuses to suckle, the milk supply can be suspended for no more than 12 hours and a hypertonic OES (containing high glucose concentration) should be, preferably, administered (SMITH, 2009; SMITH \& BERCHTOLD, 2014).

There are still doubts about which is the maximum glucose concentration in the hypertonic OES for use in calves. It should be noted that the glucose, when not absorbed, increases the risk of causing osmotic diarrhea and worsen the present condition, since it can be fermented in the large intestine with the generation of short chain volatile fatty acids, which increases the osmolarity in the lumen (SMITH, 2009). SEN et al. (2006) demonstrated that healthy calves may have osmotic diarrhea when they ingest OES containing glucose in an amount equivalent to $4.8 \mathrm{~g} \mathrm{~kg}^{-1}$ of $\mathrm{BW}$. These authors suggested that, probably, the appropriate maximum amount of glucose in the OES should be equivalent to $3.6 \mathrm{~g} \mathrm{~kg}^{-1}$ of BW. It is important to remember that in diarrheic calves the glucose absorption in the small intestine can be compromised to a greater or lesser degree according to the causative pathogen and type and the extent of the injury present.

Finally, based on the strong ion theory applied to the interpretation of acid base balance, and considering that the SID (calculated as: $\mathrm{SID}=\mathrm{Na}^{+}+\mathrm{K}^{+}$$\mathrm{Cl}^{-}$) in the calf's plasma is around $40 \mathrm{mmol} \mathrm{L}^{-1}$, it should be understood that the OES with effective SID greater than $40 \mathrm{mEq} \mathrm{L}^{-1}$ are alkalizing, while those with effective SID near zero $\mathrm{mEq} \mathrm{L}^{-1}$ are acidifying (CONSTABLE, 2003). In situations where the metabolic acidosis is mild or absent, the hydration with OES of low alkalizing power is indicated. This type of OES has, in other words, electrolyte composition, effective SID, and osmolarity similar to the plasma. When ingested, these solutions produce minimal impact on the electrolyte balance and do not cause iatrogenic acid base imbalances (BACHMANN et al., 2012).

\section{Oral electrolyte solutions in Brazil \\ Currently there are five commercial products} available in Brazil for the preparation of OES and recommended for the hydration of calves: Enerlyte ${ }^{\circledR}$ Plus (Virbac do Brasil Indústria e Comércio Ltda.), Glutellac $^{\circledR}$ (Bayer Saúde Animal), Hydrafeed ${ }^{\circledR}$ (Hypred Brasil Indústria e Comércio de Produtos de Higiene e Limpeza Ltda.), Nutronlyt ${ }^{\circledR}$ (Nutron Alimentos Ltda.), and Rehydion ${ }^{\circledR}$ Gel (Ceva Saúde Animal Ltda.). The emergence of these products in the market proves that the interest in oral hydration is expanding in the country, which means an important mark in the modernization of therapeutic practices applied to the diarrheic calves. Even in the face of this innovation, Brazil is still far from countries of North America and Europe where the use of OES for the treatment of diarrheic and dehydrated calves is routine and there are several commercially available alternatives.

The oldest product in the Brazilian market is the Nutronlyt ${ }^{\mathbb{R}}$, which was introduced in 2005. Seven years later, in 2012, the Glutellac ${ }^{\circledR}$ was released. Successively, Enerlyte ${ }^{\circledR}$ Plus, Hydrafeed ${ }^{\circledR}$, and Rehydion ${ }^{\circledR}$ Gel were released in 2014. Among them, only the Nutronlyt ${ }^{\circledR}$ is produced in Brazil. Enerlyte ${ }^{\circledR}$ Plus is produced in Italy, Glutellac ${ }^{\circledR}$ in New Zealand, Hydrafeed $^{\circledR}$ in France, and Rehydion ${ }^{\circledR}$ Gel in Germany. These electrolyte replacers are sold ready to be diluted in water and given to the calf. They are indicated for the hydration of calves, are supposedly alkalizing, having sodium bicarbonate or sodium acetate, and contain glucose or lactose as energy source.

Enerlyte ${ }^{\circledR}$ Plus, Hydrafeed ${ }^{\circledR}$, and Nutronlyt ${ }^{\circledR}$ are presented in powder. Glutellac ${ }^{\circledR}$ is liquid and Rehydion $^{\circledR}$ Gel is gelatinous, as the name suggests. The $100 \mathrm{~g}$ packet of Enerlyte ${ }^{\circledR}$ Plus and Hydrafeed ${ }^{\circledR}$, as well as the amount of $100 \mathrm{~g}$ of Nutronlyt ${ }^{\circledR}$, must be diluted with $2 \mathrm{~L}$ of water. A $50 \mathrm{~mL}$ vial of Glutellac ${ }^{\circledR}$ and the volume of $40 \mathrm{~mL}$ of Rehydion ${ }^{\circledR}$ Gel are suitable for dilution with the same volume of water (2L). Thus, regardless of the chosen product, $2 \mathrm{~L}$ of the OES will be prepared. The price per liter of prepared OES is variable and is around US\$ 0.84 with Nutronlyt ${ }^{\mathbb{B}}$; US\$ 1.15 with Rehydion ${ }^{\circledR}$ Gel; US\$ 1.33 with Glutellac ${ }^{\circledR}$; US\$ 2.04 with Enerlyte ${ }^{\circledR}$ Plus, and US\$ 2.63 with Hydrafeed ${ }^{\circledR}$. These prices were searched with resellers in the state of Parana, Brazil, and one USD was equivalent to R\$3.19. 
In order to confirm and demonstrate the compositions of the different OES prepared, each of the commercial product was diluted in $2 \mathrm{~L}$ of distilled water heated to $38^{\circ} \mathrm{C}$, and homogenized as recommended by the manufacturers. The $\mathrm{pH}$ and the concentrations of $\mathrm{HCO}_{3}^{-}, \mathrm{Na}^{+}, \mathrm{K}^{+}$e $\mathrm{Cl}^{-}$were measured (Omni C; Cobas B 121; Roche Diagnóstica do Brasil Ltda.), the glucose concentration was determined (GLUC; Dimension Clinical Chemistry System; Dade Behring; Siemens), and the osmolarity was measured (Advanced MicroOsmometer Model 3320; Advanced Instruments, INC). The acetate concentration was estimated on the basis of differences between the concentrations of the electrolytes; the effective SID was calculated using the formula: effective $\mathrm{SID}=\left(\mathrm{Na}^{+}+\mathrm{K}^{+}\right)-(\mathrm{Cl}$ ) ; and the relations $\mathrm{Na}^{+}$:Glucose and $\mathrm{Na}^{+}: \mathrm{Cl}^{-}$were calculated. The results are shown in table 1. All prepared OES have nearly the same components, differing only in some of them. Enerlyte ${ }^{\circledR}$ Plus and Hydrafeed $^{\circledR}$, for example, do not have glucose but have lactose as the energy source. Regarding to the alkalizing agent, which is always combined to sodium, Enerlyte ${ }^{\circledR}$ Plus, Hydrafeed ${ }^{\circledR}$, and Nutronlyt ${ }^{\circledR}$ contain bicarbonate, while acetate is present in Glutellac $^{\circledR}$. Rehydion ${ }^{\circledR}$ Gel, conversely, has a combination of acetate and formate.

According to the osmolarity, as proposed by CONSTABLE (2003), the OES prepared with Enerlyte ${ }^{\circledR}$ Plus and with Glutellac ${ }^{\circledR}$ are considered hipoosmolar, the one prepared with Rehydion ${ }^{\circledR}$ Gel is isoosmolar, and those prepared with Hydrafeed ${ }^{\circledR}$ and Nutronlyt ${ }^{\circledR}$ are hyperosmolar. It should be noted that all solutions have osmolarity relatively close to the plasma, which is a desirable feature. None of the Brazilian OES reaches the high osmolarity of hypertonic OES marketed in North America, which contain high concentrations of glucose and are used when the milk intake is suspended or reduced.

When confronted with the concentrations indicated as appropriate for each component present in the solution (Table 1), it can be said that the OES prepared with the Brazilian commercial products have, in general, suitable compositions for therapeutic use in diarrheic calves. Despite the differences in electrolyte concentrations between them, all contain levels of $\mathrm{Na}^{+}$supposedly sufficient for the correction of hyponatremia and for optimize the renal conservation of water in the organism, which favors the reestablishment of fluid balance. All solutions contain $\mathrm{K}^{+}$and contribute to reverse the depletion that occurs in the organism due to diarrhea. All solutions have glucose or lactose, which favors the absorption of $\mathrm{Na}^{+}$and water in the intestine. And all have $\mathrm{Cl}^{-}$ concentration lower than that of $\mathrm{Na}^{+}$, indicating that they have alkalizing potential.

The OES prepared with Enerlyte ${ }^{\circledR}$ Plus, Glutellac $^{\circledR}$, Nutronlyt ${ }^{\circledR}$, and Rehydion ${ }^{\circledR}$ Gel present effective SID above $40 \mathrm{mEq} \mathrm{L}^{-1}$, and have, therefore, theoretically alkalizing effect more pronounced than the OES prepared with Hydrafeed ${ }^{\circledR}$, wich has effective SID of $38 \mathrm{mEq} \mathrm{L}^{-1}$. The alkalizing solutions are ideal for the treatment of dehydrated diarrheic calves because they commonly present varying degrees of metabolic acidosis.

The OES prepared with Nutronlyt ${ }^{\circledR}$ present higher concentrations of $\mathrm{Na}^{+}$, of $\mathrm{K}^{+}$, of $\mathrm{Cl}^{-}$and of glucose. The high concentration of glucose $(109 \mathrm{mmol}$ $\left.\mathrm{L}^{-1}\right)$ distinguishes this OES from the others and explain its high osmolarity. When the calf is deprived of milk or of milk substitutes, the intake of this OES would be an interesting option to minimize negative energy balance.

Little is known about the therapeutic efficacy of the OES prepared with the products reported in the Brazilian market. PAGLIOSA et al. (2013) conducted an experimental study, in Brazil, testing the OES prepared with Enerlyte ${ }^{\circledR}$ Plus for the treatment of dehydrated calves due to induced osmotic diarrhea. The administered OES caused alkalinization and was efficient to reverse the dehydration and restore the homeostasis in those animals. In Germany, BACHMANN et al. (2009) tested the OES prepared with Glutellac ${ }^{\circledR}$ and proved that the alkalizing effect was not intense. The effects of Rehydion ${ }^{\circledR}$ Gel was tested in healthy calves (CONSTABLE et al., 2009). However, in that study, the product was diluted in cow's milk and not in water. To date, authors are not aware of any information available in the literature about the effects induced by the OES prepared with the other commercial products.

Apart from the commercial options it is possible to prepare OES buying the individual ingredients and weighing them in the required amounts. Different formulas for different purposes can be prepared. The OES used at the Universidade Estadual de Londrina for rehydration of suckling calves is prepared with the following mixture: $3.5 \mathrm{~g}$ of $\mathrm{NaCl}, 1.5 \mathrm{~g}$ of $\mathrm{KCl}, 5 \mathrm{~g}$ of sodium acetate, and $20 \mathrm{~g}$ of anhydrous D-glucose, diluted in $1 \mathrm{~L}$ of water. This ensures $100 \mathrm{mEq} \mathrm{L}^{-1}$ of $\mathrm{Na}^{+}, 20 \mathrm{mEq} \mathrm{L}^{-1}$ of $\mathrm{K}^{+}, 86 \mathrm{mEq}$ $\mathrm{L}^{-1}$ of $\mathrm{Cl}^{-}, 35 \mathrm{mEq} \mathrm{L}^{-1}$ of acetate, and $100 \mathrm{mmol} \mathrm{L}^{-1}$ of glucose, and an osmolarity of $326 \mathrm{mOsm} \mathrm{L}^{-1}$, with effective SID of $35 \mathrm{mEq} \mathrm{L^{-1 }}$. It costs on average US\$ 0.30 per liter. Conversely, the OES used at the Universidade Federal de Viçosa in dehydrated 
Table 1 - Composition of oral electrolyte solutions commercially available in the Brazilian market and the recommended values for each component.

\begin{tabular}{|c|c|c|c|c|c|c|}
\hline & Enerlyte Plus $^{\circledR}$ & Glutellac $^{\circledR}$ & Nutronlyt $^{\circledR}$ & Rehydion Gel $^{\circledR}$ & Hydrafeed $^{\circledR}$ & Recommended $^{\mathrm{c}}$ \\
\hline $\mathrm{Na}^{+}\left(\mathrm{mEq} \mathrm{L}{ }^{-1}\right)$ & 96.8 & 100.1 & 124.6 & 120 & 95 & 90 to 130 \\
\hline $\mathrm{K}^{+}\left(\mathrm{mEq} \mathrm{L} \mathrm{L}^{-1}\right)$ & 16.1 & 18.5 & 27.7 & 22.6 & 8 & 10 to 20 \\
\hline $\mathrm{Cl}^{-}\left(\mathrm{mEq} \mathrm{L}{ }^{-1}\right)$ & 69.4 & 60.7 & 96.8 & 82 & 65 & 40 to 80 \\
\hline $\mathrm{HCO}_{3}^{-}\left(\mathrm{mEq} \mathrm{L}{ }^{-1}\right)$ & 20.9 & -- & 55.5 & -- & 38 & 40 to 80 \\
\hline Acetate $\left(\mathrm{mEq} \mathrm{L}^{-1}\right)$ & -- & $58^{\mathrm{a}}$ & -- & -- & -- & 40 to 80 \\
\hline Acetate/formate $\left(\mathrm{mEq} \mathrm{L}^{-1}\right)$ & -- & -- & -- & $60^{\mathrm{a}}$ & -- & 40 to 80 \\
\hline Glucose $\left(\mathrm{mmol} \mathrm{L}^{-1}\right)$ & $0^{\mathrm{b}}$ & 46 & 109 & 23,3 & $0^{\mathrm{b}}$ & -- \\
\hline Effective $\mathrm{SID}^{1}\left(\mathrm{mEq} \mathrm{L}^{-1}\right)$ & 43.5 & 58 & 55.5 & 60.6 & 38 & 60 to 80 \\
\hline Osmolarity $\left(\mathrm{mOsm} \mathrm{L}^{-1}\right)$ & 203 & 283 & 402.7 & 305.6 & 335 & 300 to 600 \\
\hline $\mathrm{Na}^{+}$:glucose & -- & $2.1: 1$ & $1.1: 1$ & $5.1: 1$ & -- & $1: 1$ to $3: 1$ \\
\hline $\mathrm{Na}^{+} \mathrm{Cl}^{-}$ & $1.4: 1$ & $1.6: 1$ & $1.3: 1$ & $1.4: 1$ & $1.4: 1$ & -- \\
\hline $\mathrm{Ph}$ & 7.021 & 6.232 & 7.952 & 6.606 & 6.415 & -- \\
\hline
\end{tabular}

${ }^{1} \mathrm{SID}$ : Strong ion difference; calculated by $\left(\left[\mathrm{Na}^{+}\right]+\left[\mathrm{K}^{+}\right]\right)-\left[\mathrm{Cl}^{-}\right]$; ${ }^{\text {a }}$ calculated value; ${ }^{\mathrm{b}}$ contain lactose. ${ }^{\mathrm{c}} \mathrm{CONSTABLE}$ et al. (2001); CONSTABLE (2003) and SMITH (2009).

calves with diarrhea is composed by $4 \mathrm{~g}$ of $\mathrm{NaCl}, 1 \mathrm{~g}$ of $\mathrm{KCl}, 4 \mathrm{~g}$ of sodium acetate and $10 \mathrm{~g}$ of dextrose diluted in $1 \mathrm{~L}$ of water (osmolarity: $248 \mathrm{mOsm} \mathrm{L}^{-1}$ ), with an average cost of US\$ 0.12 per liter (one USD equivalent to $\mathrm{R} \$ 3.19$ ).

The effectiveness of non-commercial OES has been tested, in Brazil, to correct dehydration in calves due to induced osmotic diarrhea (FERREIRA, 2001; LEAL et al., 2012) and naturally acquired diarrhea (FREITAS, 2013). Solutions used by these researchers contain basically the same components of commercially available solutions. FREITAS (2013) compared two types of OES with different alkalizing agents and stated that both, a bicarbonate-containing OES and an acetate-containing OES, were equally effective in reversing the water imbalance of neonatal calves. Both OES were able to prevent the worsening of metabolic acidosis, causing the calves to remain only with mild acidemia during the patency period of diarrhea. In the case of osmotically induced diarrhea, FERREIRA (2001) used OES containing bicarbonate and LEAL et al. (2012) used OES containing acetate and both showed that, regardless of the alkalizing agent present in OES, there was a reestablishment of hydroelectrolytic balance, reversal of hypoglycemia and correction of metabolic acidosis.

Although non-commercial OES are proven to be efficient and cheaper, commercial OES are considered more practical because it avoids the additional work of buying the ingredients and weighing them for preparation.

\section{CONCLUSION}

The use of OES in calves with water, electrolyte and acid base imbalances is indispensable. Most commercially available $\mathrm{OES}$ contain $\mathrm{HCO}_{3}{ }^{-}$and glucose, have alkalizing potential, vary from hypotonic to hypertonic and are cheaper than intravenous electrolyte solutions. Increase in commercial availability and in the use of these solutions is remarkable in recent years in Brazil, indicating advances and modernization in therapeutic practice in the treatment of diarrheic calves. The OES prepared with the commercial products available in the country have suitable compositions for this purpose.

\section{ACQUISICION SOURCE}

Enerlyte ${ }^{\circledR}$ Plus, Virbac do Brasil Indústria e Comércio Ltda. Glutellac $^{\circledR}$, Bayer Saúde Animal.

Hydrafeed $^{\circledR}$, Hypred Brasil Indústria e Comércio de Produtos de Higiene e Limpeza Ltda.

Nutronlyt ${ }^{\mathbb{R}}$, Nutron Alimentos Ltda.

Rehydion ${ }^{\circledR}$ Gel, Ceva Saúde Animal Ltda.

\section{ACKNOWLEDGEMENTS}

Júlio A.N. Lisbôa is recipient of the Conselho Nacional de Desenvolvimento Científico e Tecnológico (CNPq) fellowship.

\section{REFERENCES}

LANGONI, H. et al. Contribution to the study of diarrhea etiology in neonate dairy calves in São Paulo state, Brazil. Brazilian Journal of 
Veterinary Research and Animal Science, v.41, n.5, p.313-319, 2004. Available from: <http://www.scielo.br/pdf/bjvras/v41n5/25255.pdf $>$. Accessed: Mar. 15, 2016. doi: 10.1590/S1413-95962004000500004.

BACHMANN, L. et al. Influence of different oral rehydration solutions on abomasal conditions and the acid-base status of suckling calves. Journal of Dairy Science, v.92, n.4, p.1649-1659, 2009. Available from: <http://dx.doi.org/10.3168/jds.2008-1487>. Accessed: Feb. 10, 2016. doi: 10.3168/jds.2008-1487.

BACHMANN, L. et al. Change of plasma volume, osmolality, and acid - base status in healthy calves after feeding of milk and waterand milk-based oral rehydration solutions. Journal of Dairy Science, v.95, n.10, p.6006-6014, 2012. Available from: <http:// dx.doi.org/10.3168/jds.2012-5562>. Accessed: Apr. 21, 2016. doi: $10.3168 /$ jds.2012-5562.

BERCHTOLD, J. Treatment of calf diarrhea: intravenous fluid therapy. Veterinary Clinics of North America: Food Animal Practice, v.25, n.1 p.73-99, 2009. Available from: $<$ http://www. sciencedirect.com/science/article/pii/S074907200800087X $>$. Accessed: Nov. 24, 2015. doi: 10.1016/j.cvfa.2008.10.001.

CONSTABLE, P.D. et al. Comparison of two electrolyte solutions for the treatment of dehydrated calves with experimentally-induced diarrhea. Veterinary Journal, v.2, n.162, p.129-140, 2001. Available from: <http://www.ncbi.nlm.nih.gov/pubmed/11531397>. Accessed: Nov. 4, 2015. doi:10.1053/tvj1.2000.0553.

CONSTABLE, P.D. Fluid and electrolyte therapy in ruminants. Veterinary Clinics of North America: Food Animal Practice, v.19, n.3, p.557-597, 2003. Available from: <http://www.ncbi. nlm.nih.gov/pubmed/14608802>. Accessed: Dec. 14, 2015. doi: 10.1016/S0749-0720(03)00054-9.

CONSTABLE, P.D. et al. Comparative effects of two oral rehydration solutions on milk clotting, abomasal luminal $\mathrm{pH}$, and abomasal emptying rate in suckling calves. Journal of Dairy Science, v.92, n.1, p.296-312, 2009. Available from: <https://www ncbi.nlm.nih.gov/pubmed/19109288>. Accessed: Nov. 13, 2015. doi: $10.3168 /$ jds.2008-1462.

FERREIRA, F. Fluidoterapia endovenosa e oral em bezerros com diarreia osmótica induzida. 2001. 73f. Dissertação (Mestrado em Clínica e Cirurgia Veterinária) - Escola de Veterinária, Universidade Federal de Minas Gerais, MG.

FETTMAN, M.J. et al. Evaluation of commercial oral replacement formulas in healthy neonatal calves. Journal of the American Veterinary Medical Association, v.188, n.4, p.397-401, 1986. Available from: <http://www.ncbi.nlm.nih.gov/pubmed/3949616>. Accessed: Sept. 25, 2015.

FREITAS, M.D. Avaliação de soluções eletrolíticas orais em bezerros neonatos durante o curso da diarreia. 2013. 108f. Tese (Doutorado em Clínica e Cirurgia Veterinária) - Escola de Veterinária, Universidade Federal de Minas Gerais, MG.

GARTHWAITE, B.D. et al. Whole milk and oral rehydration solution for calves with diarrhea of spontaneous origin. Journal of Dairy Science, v.77, n.3, p.835-843, 1994. Available from: <http://www. ncbi.nlm.nih.gov/pubmed/8169291>. Accessed: Sept. 24, 2015.

GOODELL, G.M. et al. An alkalinizing oral rehydration solution containing lecithin-coated citrus fiber is superior to a nonalkalinizing solution in treating 360 calves with naturally acquired diarrhea.
Journal of Dairy Science, v.95, n.11, p.6677-6686, 2012. Available from: <http://dx.doi.org/10.3168/jds.2012-5605>. Accessed: Mar. 20, 2016. doi: 10.3168/jds.2012-5605.

JODAL, M.; LUNDGREN, O. Countercurrent mechanisms in the mammalian intestinal tract. Gastroenterology, v.91, n.1, p.225-241, 1986. Available from: <http://www.ncbi.nlm.nih.gov/ pubmed/3519349>. Accessed: Apr. 23, 2016.

LEAL, M.L.R. et al. Intravenous hypertonic saline solution (7,5\%) and oral electrolytes to treat of calves with noninfectious diarrhea and metabolic acidosis. Journal of Veterinary Internal Medicine, v.26, n.4, p.1042-1050, 2012. Available from: <https:/www.ncbi.nlm.nih.gov/pubmed/22708669>. Accessed: Mar. 16, 2017. doi: 10.1111/j.1939-1676.2012.00960.x.

LEVY, M. et al. Comparison of the effects of an isosmolar and hyperosmolar oral rehydrating solution on the hydration status, glycemia and ileal content composition of healthy neonatal calves. Cornell Veterinarian, v.80, n.2, p.143-151, 1990. Available from: $<\mathrm{http} / / / \mathrm{www}$. ncbi.nlm.nih.gov/pubmed/2318040>. Accessed: May. 14, 2016.

MARSHALL, T.S. et al. Effect of suckling an isotonic solution of sodium acetate, sodium bicarbonate or sodium chloride on abomasal emptying rate and luminal $\mathrm{pH}$ in calves. American Journal of Veterinary Research, v.69, n.6, p.824-831, 2008. Available from: $<$ http://www.ncbi.nlm.nih.gov/pubmed/18518665>. Accessed: Nov. 17, 2015. doi: 10.2460/ajvr.69.6.824.

MILLEMANN, Y. Diagnosis of neonatal calf diarrhoea. Revue de Médecine Vétérinaire, v.160, n.8-9, p.404-409, 2009. Available from: <http://www.revmedvet.com/2009/RMV160_404_409.pdf $>$. Accessed: Dec. 28, 2015.

NAYLOR, J.M. Oral fluid therapy in neonatal ruminants and swine. Veterinary Clinics of North America: Food Animal Practice, v.6, n.1, p.51-67, 1990. Available from: <http://dx.doi. org/10.1016/S0749-0720(15)30894-X>. Accessed: Sept. 16, 2015. doi: $10.1016 / \mathrm{S} 0749-0720(15) 30894$.

NAYLOR, et al. Advances in oral and intravenous fluid therapy of calves with gastrointestinal disease. In: WORLD BUIATRIC CONGRESS, 2006, Nice, França. Proceedings... Nice: WBC, 2006. Available from: <http://www.ivis.org/proceedings/wbc/ wbc2006/naylor.pdf?LA=>. Accessed: Jan. 24, 2016.

NOURI, M.; CONSTABLE, P.D. Comparison of two oral electrolyte solutions and route of administration on the abomasal emptying rate of Holstein-Friesian calves. Journal of Veterinary Internal Medicine, v.20, n.3, p.620-626, 2006. Available from: <http://www. ncbi.nlm.nih.gov/pubmed/16734099>. Accessed: Jan. 15, 2016. doi: 0891-6640/06/2003-0023.

PAGLIOSA, G.M. et al. Hidratação enteral associada ou não a antimicrobiano no tratamento de bezerros com diarreia experimentalmente induzida. Arquivos de Ciência Veterinária e Zoologia da UNIPAR, v.16, n.2, p.113-120, 2013. Available from: $\quad<$ http://revistas.unipar.br/?journal=veterinaria\&page=ar ticle\&op=view\&path $\% 5 \mathrm{~B} \% 5 \mathrm{D}=4497 \&$ path $\% 5 \mathrm{~B} \% 5 \mathrm{D}=2718>$. Accessed: Feb. 19, 2016.

RADOSTITS, O.M. et al. Veterinary Medicine - A textbook of the diseases of cattle, horses, sheep, pigs and goats. 10.ed. Philadelphia: Saunders Elsevier, 2007. 2156p.

RIBEIRO FILHO, J.D. et al. Hidratação enteral em bovinos: avaliação de soluções eletrolíticas isotônicas administradas por 
sonda nasogástrica em fluxo contínuo. Ciência Rural, v.41, n.2, p.285-290, 2011. Available from: <http://www.scielo.br/pdf/cr/ v41n2/a874cr3631.pdf>. Accessed: Feb. 26, 2016.

RODRIGUES, R.R. et al. Alimentação de bezerros ruminantes com dieta sólida ou líquida, via goteira esofageana : formação da goteira e escape ruminal. Revista Brasileira de Zootecnia, v.31, n.6, p.2364-2372, 2002. Available from: <http://dx.doi. org/10.1590/S1516-35982002000900027>. Accessed: Dec. 17, 2015. doi: $10.1590 / \mathrm{S} 1516-35982002000900027$.

ROUSSEL, A.J. Fluid therapy in mature cattle. Veterinary Clinics of North America: Food Animal Practice, v.30, n.2, p.429-439, 2014. Available from: <http://dx.doi.org/10.1016/j.cvfa.2014.04.005>. Accessed: Apr. 20, 2016. doi: 10.1016/j.cvfa.2014.04.005.

SANTOSHAM, M. et al. Oral rehydration therapy for diarrhea: an example of reverse transfer of technology. Pediatrics, v.100, n.5, p.1-5, 1997. Available from: <http://pediatrics.aappublications.org/ content/pediatrics/100/5/e10.full.pdf?ck=nck $>$. Accessed: Mar. 14, 2016. doi: $10.1542 /$ peds. $100.5 \mathrm{e} 10$.

SEN, I. et al. Effect of suckling isotonic or hypertonic solutions of sodium bicarbonate or glucose on abomasal emptying rate in calves. American Journal of Veterinary Research, v.67, n.8, p.1377-1384, 2006. Available from: <http://avmajournals.avma.org/doi/pdf/10.2460/ ajvr.67.8.1377>. Accessed: Mar. 12, 2016. doi: 10.2460/ajvr.67.8.1377.
SEN, I. et al. Efficacy of oral rehydration therapy solutions containing sodium bicarbonate or sodium acetate for treatment of calves with naturally acquired diarrhea, moderate dehydration, and strong ion acidosis. Jounal of the American Veterinary Medical Association, v.234, n.7, p.926-934, 2009. Available from: <http:// www.ncbi.nlm.nih.gov/pubmed/19335244>. Accessed: May 27, 2016. doi: 10.2460/javma.234.7.926.

SMITH, G.W. Treatment of calf diarrhea : oral fluid therapy. Veterinary clinics of North America: Food Animal Practice, v.25, n.1, p.55-72, 2009. Available from: <http://dx.doi.org/10.1016/j. cvfa.2008.10.006>. Accessed: June. 14, 2016. doi: 10.1016/j. cvfa.2008.10.006.

SMITH, G.W. et al. Effect of orally administered electrolyte solution formulation on abomasal luminal $\mathrm{pH}$ and emptying rate in dairy calves. Jounal of American Veterinary Medical Association, v.241, n.8, p.1075-1082, 2012. Available from: $<$ http://www.ncbi.nlm.nih.gov/pubmed/23039985>. Accessed: May. 21, 2016. doi: 10.2460/javma.241.8.1075.

SMITH, G.W.; BERCHTOLD, J. Fluid therapy in calves fluid therapy calves diarrhea strong ion acidosis. Veterinary Clinics of North America: Food Animal Practice, v.30, n.2, p.409-427, 2014. Available from: <http://dx.doi.org/10.1016/j. cvfa.2014.04.002>. Accessed: June. 15, 2016. doi: 10.1016/j. cvfa.2014.04.002. 